\title{
The protein quality of cassava leaves
}

\author{
By B. O. EGGUM \\ Department of Physiology and Chemistry, Agricultural Research \\ Laboratory, DK-1958 Copenhagen V, Denmark \\ (Received 18 December 1969-Accepted 3 March 1970)
}

\begin{abstract}
I. A chemical and biological evaluation of the protein content of some leaves and leaf extracts from the eastern region of Nigeria (Biafra) has been made: most were from cassava (Manihot utilissima).

2. The protein content of the leaves was from 30 to $40 \%$ (expressed as percentage of leaf dry matter). The concentrations of essential amino acids were adequate, except for methionine. The biological criteria, true digestibility (TD) and biological value (BV), showed that the digestibility was from 70 to $80 \%$, whereas BV varied from 44 to $57 \%$, depending on the methionine content.

3. Adding methionine to a diet of cassava leaves raised BV from 49 for the leaves alone to 80 for the mixture. This relationship clearly shows that cassava leaves contain too little available methionine. An investigation into the true availability of the amino acids showed that this is somewhat variable, and only $60 \%$ of the methionine is available.

4. The BV of cassava leaves combined with Norwegian dried cod showed a mutual supplementation effect.
\end{abstract}

In connexion with the famine occurring during the recent civil war in Nigeria, the Agricultural Research Laboratory in Copenhagen received cassava (Manihot utilissima) leaves for analysis and examination of the protein quality.

Cassava leaves are not normally regarded as a source of protein (Irvine, 1952; Okiy, I960) though the root is a valuable source of carbohydrate. According to Oke (I968) cassava leaves are rich in protein, carotenes, vitamins $B_{1}, B_{2}$ and $C$, and minerals, but the cyanide content has precluded their use as a vegetable in Nigeria. However, Dalziel (I955) says the young shoots of the sweet variety are eaten in the Cameroons.

The biggest objection to cassava leaves as a food is undoubtedly the content of cyanide. Rogers \& Milner ( 1963 ) reported that a cyanide level equivalent to that in manioc (cassava) leaf was not toxic to rats fed with casein, as judged by the effects on growth and methaemoglobin levels in the blood. Recently, leaves have been boiled, in an open pot, for 5-10 min to drive off cyanide, if present (N. A. Nwosu, 1969, personal communication).

Though the high protein content of cassava leaves is well established, there is still some doubt about its quality. Rogers (1959) found that cassava leaves at the age of I I-I 2 months contained from 20.6 to $30.4 \%$ crude protein expressed as a percentage of the leaf dry matter. Rogers \& Milner (rg63) later reported that the protein content of manioc leaves (on a dry-weight basis) varied from 17.8 to $34.8 \%$ for Brazilian material and from $18 \cdot 5$ to $32.4 \%$ for Jamaican varieties. The amino acid composition of all varieties indicated that the protein in cassava leaves is deficient in methionine, and possibly marginal in tryptophan, in relation to the FAO reference protein. The 
lysine content, however, is high, averaging $7 \cdot 20 \mathrm{~g} / \mathrm{I} 6 \mathrm{~g}$ nitrogen for the Jamaican and $6.33 \mathrm{~g} / \mathrm{r} 6 \mathrm{~g} \mathrm{~N}$ for the Brazilian varieties respectively. Gerloff, Lima \& Stahmann (1965) compared the average essential amino acid values for leaf-protein concentrates to those for milk, cheese, meat, poultry, fish and egg protein: only the amounts of isoleucine, lysine and methionine were consistently lower than in animal products. Threonine was consistently higher, while the remainder of the amino acids were in favourable balance. Samples from nine plant species harvested under different conditions of fertilization and maturity did not show large variations in amino acid content. Gerloff et al. (1965) concluded that, on a total amino acid compositional basis, leafprotein concentrate should be a well-balanced source of dietary protein if supplemented with synthetic methionine.

Van Veen (1938) and Luyken, de Groot \& van Stratum (1961) found a high digestibility of the protein in cassava leaves, especially with the young leaves. Luyken et al. ( 1961 ) found a true digestibility of $80 \%$ for the protein in young leaves, but this decreased to $67 \%$ in older leaves; they also found an increase in net protein utilization (NPU) in older leaves when supplemented with methionine. Rogers \& Milner (1963) could not make rats eat adequate amounts of the manioc-leaf diet and the animals lost weight. Reducing the amount of manioc leaf in the diet and sweetening it with sucrose did not improve the feed intake.

Some work has been done on extracting protein from cassava leaves: Byers ( $196 \mathrm{I}$ ) and Singh ( 1964$)$ say that not much protein $(<15 \%)$ is extractable from fresh leaves. Akinrele (I963) agrees with this, but goes on to show that not all methods of extraction give the same results. He also mentions that leaf protein is a poor source of methionine, and ideally needs to be supplemented with another protein relatively rich in this amino acid.

In a chemical study on the more commonly used leaf vegetables in Nigeria, Oke (I966) showed that the crude-fibre content of cassava leaves ranged from 6.4 to $10.3 \%$, ether extractives from $\mathrm{I} \cdot 47$ to $4 \cdot 20 \%$ and the calcium : phosphorus ratio from $\mathrm{I} \cdot 0$ to $7 \cdot 0$ ( 0.5 is normally regarded as satisfactory). A low crude-fibre content is advantageous when considering the use of products for human nutrition.

The results so far discussed show that the protein in cassava leaves is of quite good biological value. This, along with the high protein content of the leaf, indicates that these leaves might be a useful, and acceptable, source of protein for human nutrition (Terra, I964).

EXPERIMENTAL

\section{Brief description of the samples investigated}

\begin{tabular}{cl}
$\begin{array}{c}\text { Sample } \\
\text { no. }\end{array}$ & \multicolumn{1}{c}{ Description } \\
I & Leaves from Eupatorium odoratum (Queens weed) \\
2 & Leaf extract from E. odoratum \\
3 & Leaf extract from Manihot utilissima Pohl (cassava) \\
4 & Leaf extract from Panicum maximum Jacq. (Guinea grass) \\
5 & Leaves from cassava, variety 6r584 Ohupon (a bitter species) \\
6 & Leaves from cassava, variety GCH (a bitter species) \\
7 & Leaves from cassava, variety 44086 Congo (Panja-a sweet species) \\
8 & Leaves from Morus indica L. (mulberry)
\end{tabular}


Samples I, 5, 6, 7 and 8 consisted of young leaves, sun-dried in Nigeria (Biafra). Leaf extracts 2, 3 and 4 were produced according to local procedure (N. A. Nwosu, I969, personal communication), using equipment found within any West African household (e.g. pestles and mortars, boiling cans, wooden spoons, fine wire mesh sieves and cloth bags).

\section{Procedure}

The leaf extracts discussed here originated from freshly harvested green leaves. The leaves are washed in water to remove dust and then ground in a mortar until the leaf material is ruptured. The sap is then expressed by hand (or in a press if available) in the same way as palm oil is expressed. The liquid obtained is passed through a fine wire mesh sieve to remove leaf debris. This filtrate is boiled in an open can for $5-10 \mathrm{~min}$ to coagulate the protein. The precipitated material is cooled and repeatedly washed with water until the rinsing water becomes colourless. The coagulum is poured into a cloth and strained to remove as much water as possible: it is then spread on a tray to dry in the sun.

\section{RESULTS AND DISCUSSION}

When sufficient material was available, a complete analysis, including determination of some minerals, was carried out in addition to the tests for protein quality.

The results of the leaf analyses are shown in Table $\mathrm{x}$. The crude- and true-protein contents of the leaf samples were similar to those previously reported. The ash

Table I. Proximate analysis and mineral composition of some leaves and leaf extracts

\begin{tabular}{|c|c|c|c|c|c|c|c|c|}
\hline \multirow[b]{2}{*}{$\begin{array}{c}\text { Sample } \\
\text { no.* }\end{array}$} & \multicolumn{7}{|c|}{ (All results as \% dry matter) } & \multirow[b]{2}{*}{8} \\
\hline & I & 2 & 3 & 4 & 5 & 6 & 7 & \\
\hline Ash & 10.41 & - & - & - & $5 \cdot 20$ & $5 \cdot 96$ & $5 \cdot 34$ & 8.31 \\
\hline $\begin{array}{l}\text { Crude } \\
\text { protein }\end{array}$ & $33 \cdot 12$ & $35 \cdot 56$ & $34 \cdot 56$ & $37 \cdot 31$ & 35.04 & $37^{\circ} 40$ & $32 \cdot 85$ & $31 \cdot 26$ \\
\hline $\begin{array}{l}\text { Ether } \\
\text { extract }\end{array}$ & $5 \cdot 82$ & 一 & - & - & $5 \cdot 96$ & 6.08 & $5 \cdot 74$ & $7 \cdot 39$ \\
\hline $\begin{array}{l}\text { Crude } \\
\text { fibre }\end{array}$ & $9 \cdot 76$ & - & - & - & I I $\cdot 76$ & 10.96 & I I $\cdot 38$ & $8 \cdot 67$ \\
\hline $\begin{array}{l}\text { N-free } \\
\text { extracts }\end{array}$ & 40.89 & - & 一 & - & $42 \cdot 04$ & $39 \cdot 87$ & 44.79 & $43 \cdot 87$ \\
\hline $\begin{array}{l}\text { True pro- } \\
\text { tein }\end{array}$ & $23 \cdot 29$ & - & - & - & 29.45 & 30.73 & 30.42 & $27 \cdot 10$ \\
\hline $\mathrm{Ca}$ & 0.79 & 0.60 & $I \cdot 12$ & I.04 & 0.62 & 0.68 & 0.75 & $1 \cdot 37$ \\
\hline $\mathbf{P}$ & 0.37 & 0.20 & 0.22 & 0.17 & 0.30 & 0.31 & 0.30 & 0.40 \\
\hline $\mathrm{Na}$ & 0.18 & 0.12 & 0.15 & 0.14 & 0.10 & 0.10 & 0.14 & 0.17 \\
\hline $\mathrm{Mg}$ & 0.73 & 0.05 & 0.05 & 0.03 & 0.28 & $0.3 I$ & 0.29 & 0.35 \\
\hline
\end{tabular}

content was approximately on a level with that of many oil-cakes, whereas the crudefibre content was about 10\%. These findings are in line with results by Oke (Ig66) made on leaf vegetables in Nigeria. The values for calcium, sodium and magnesium, however, are somewhat lower. 


\section{Amino acid composition of leaf extracts}

The amino acid analyses were carried out according to the method of Moore, Spackman \& Stein (1958), and methionine and cystine were estimated as methionine sulphone and cysteic acid respectively. The method of hydrolysis used was that described by Weidner \& Eggum (1966). Tryptophan was measured according to the method of Eggum (1968a), but proline was not estimated.

Table 2. Amino acid composition ( $g / 16 \mathrm{~g}$ nitrogen) of protein extracted from some species of leaves

\begin{tabular}{|c|c|c|c|}
\hline Amino acid & $\begin{array}{l}\text { Eupatorium } \\
\text { odoratum }\end{array}$ & $\begin{array}{l}\text { Manihot } \\
\text { utilissima }\end{array}$ & $\begin{array}{l}\text { Panicum maximum } \\
\text { (Guinea grass) }\end{array}$ \\
\hline Lysine & 5.88 & $6 \cdot 28$ & $5 \cdot 20$ \\
\hline Methionine & $2 \cdot 42$ & $2 \cdot 07$ & $2 \cdot 26$ \\
\hline Cystine & 0.86 & $1 \cdot 29$ & 0.98 \\
\hline Methionine + cystine & $3 \cdot 28$ & $3 \cdot 36$ & $3 \cdot 24$ \\
\hline Aspartic acid & 10.09 & 9.57 & $8 \cdot 90$ \\
\hline Threonine & $4 \cdot 94$ & $4 \cdot 53$ & $4 \cdot 42$ \\
\hline Serine & $4 \cdot 25$ & $4 \cdot 47$ & $4 \cdot 28$ \\
\hline Glutamic acid & II 00 & 10.97 & 10.21 \\
\hline Glycine & $5 \cdot 4 I$ & $5 \cdot 20$ & 5.09 \\
\hline Alanine & 5.94 & $5 \cdot 71$ & $5 \cdot 82$ \\
\hline Valine & 5.92 & $5 \cdot 80$ & $5 \cdot 78$ \\
\hline Isoleucine & 4.99 & $5 \cdot 10$ & $4 \cdot 96$ \\
\hline Leucine & 8.99 & $9^{* 17}$ & 9.01 \\
\hline Tyrosine & 4.53 & 4.30 & 3.66 \\
\hline Phenylalarine & 5.78 & $5 \cdot 89$ & 5.65 \\
\hline Histidine & $1 \cdot 94$ & $2 \cdot 27$ & $\mathrm{r} \cdot 86$ \\
\hline Arginine & 5.79 & $5 \cdot 55$ & $5 \cdot 29$ \\
\hline Tryptophan & $2 \cdot 16$ & $1 \cdot 77$ & $1 \cdot 62$ \\
\hline
\end{tabular}

The amino acid composition of the three leaf extracts is given in Table 2. All three have a similar amino acid composition, although there is less lysine in the Panicum maximum extract. There is good agreement between these figures and those obtained by Rogers \& Milner ( 1963 ) on similar preparations. The content of most of the essential amino acids is higher than in soya-bean meal (Eggum, I $968 b$ ), particularly for threonine and tryptophan. The concentration of the sulphur-containing amino acids, cystine and methionine, is probably too low to supply human demand, and this will possibly be the limiting factor with these preparations. However, the high protein content of the extracts should ensure the supply of considerable amounts of essential amino acids to the human diet.

\section{Amino acid composition and protein quality of the leaves}

In addition to the analyses already mentioned, a biological evaluation of the protein was done on leaf samples $\mathrm{I}, 5,6$ and 7 by means of rats, according to the method of Mitchell (Eggum \& Mercer, 1964) with the test materials supplying 10\% crude protein to each diet, and the true availability of the amino acids was measured (Eggum, I966). In the biological evaluation protein values are expressed as follows: true digestibility, $\mathrm{TD}$; biological value, $\mathrm{BV}$; net protein utilization, $\mathrm{NPU}=\mathrm{TD} \times \mathrm{BV} / \mathrm{IOO}$; utilizable nitrogen, $\mathrm{UN}=(\%$ of sample $) \times \mathrm{NPU} / \mathrm{IOO}$. 
The amino acid composition of five leaf samples, and the protein quality of four of them is shown in Table 3 .

The amino acid composition of the whole leaves was similar to that of the extracts (Table 2). The concentration of the sulphur-containing amino acids was rather low, and this was probably the cause of the relatively low BV, which ranged from 43.8 to $57^{\circ}$. The sample with the highest methionine content, the cassava variety 44086 Congo, had the highest $\mathrm{BV}$ at $57 \cdot \mathrm{I}$.

Table 3. Amino acid composition ( $\mathrm{g} / \mathrm{I} 6 \mathrm{~g}$ nitrogen) and protein quality of different leaves from Biafra

\begin{tabular}{|c|c|c|c|c|c|}
\hline Amino acid & $\begin{array}{c}\text { Eupatorium } \\
\text { odoratum } \\
\text { (Queens weed) }\end{array}$ & $\begin{array}{c}\text { Cassava } \\
\text { (variety 61584 } \\
\text { Ohupon) }\end{array}$ & $\begin{array}{c}\text { Cassava } \\
\text { (variety GCH) }\end{array}$ & $\begin{array}{c}\text { Cassava } \\
\text { (variety } 44086 \\
\text { Congo) }\end{array}$ & $\begin{array}{l}\text { Morus indica L. } \\
\text { (mulberry) }\end{array}$ \\
\hline $\begin{array}{l}\text { Lysine } \\
\text { Methionine }\end{array}$ & $\begin{array}{l}4 \cdot 67 \\
1 \cdot 59\end{array}$ & $\begin{array}{l}5 \cdot 87 \\
1 \cdot 86\end{array}$ & $\begin{array}{l}5 \cdot 61 \\
1 \cdot 83\end{array}$ & $\begin{array}{l}6 \cdot 45 \\
2 \cdot 07\end{array}$ & $\begin{array}{r}5.99 \\
\mathrm{r} \cdot 8 \mathrm{I}\end{array}$ \\
\hline Cystine & $1 \cdot 08$ & $I \cdot 40$ & $1 \cdot 52$ & I. 55 & $\mathrm{I} \cdot 39$ \\
\hline Methionine + cystine & $2 \cdot 67$ & $3 \cdot 26$ & $3 \cdot 35$ & $3 \cdot 62$ & $3 \cdot 20$ \\
\hline Aspartic acid & $9 \cdot 33$ & $9 \cdot 77$ & $10 \cdot 26$ & II·06 & 10.00 \\
\hline Threonine & 3.52 & 439 & $4: 34$ & $4 \cdot 69$ & 4.14 \\
\hline Serine & $3 \cdot 20$ & $4 \cdot 55$ & 4.62 & $5 \cdot 18$ & 4.09 \\
\hline Glutamic acid & $8 \cdot 37$ & $12 \cdot 32$ & $12 \cdot 37$ & $13 \cdot 78$ & $\mathrm{IX} \cdot 32$ \\
\hline Glycine & $3 \cdot 88$ & $4 \cdot 86$ & $4 \cdot 79$ & $5 \cdot 35$ & 4.89 \\
\hline Alanine & 4.05 & $5 \cdot 73$ & $5 \cdot 75$ & $6 \cdot 24$ & $5 \cdot 45$ \\
\hline Valine & 4.39 & $5 \cdot 56$ & 5.39 & 6.23 & 5.69 \\
\hline Isoleucine & $3 \cdot 69$ & $4^{\circ} 5^{\circ}$ & $4 \cdot 26$ & $4 \cdot 86$ & $4 \cdot 46$ \\
\hline Leucine & $5 \cdot 95$ & $8 \cdot 19$ & $8 \cdot 1 \mathrm{I}$ & $8 \cdot 82$ & $7 \cdot 88$ \\
\hline Tyrosine & $3 \cdot 05$ & $4 \cdot 04$ & 4.07 & $3 \cdot 95$ & $3 \cdot 93$ \\
\hline Phenylalanine & $4^{-03}$ & $5 \cdot 42$ & $5 \cdot 33$ & $5 \cdot 49$ & $5 \cdot 00$ \\
\hline Histidine & $\mathrm{I} \cdot 58$ & $2 \cdot 30$ & $2 \cdot 24$ & $2 \cdot 47$ & $2 \cdot 20$ \\
\hline Arginine & 4.55 & $5 \cdot 34$ & $5 \cdot 10$ & $5 \cdot 50$ & $5 \cdot 89$ \\
\hline Tryptophan & $I \cdot 32$ & I.99 & $2 \cdot 16$ & $2 \cdot 23$ & $1 \cdot 52$ \\
\hline $\mathrm{N}$ as $\%$ of dry matter & $5 \cdot 30$ & $5 \cdot 61$ & $5 \cdot 98$ & $5 \cdot 26$ & $5^{\cdot 00}$ \\
\hline \multicolumn{6}{|c|}{ Protein value expressed as $(\%)$ : } \\
\hline True digestibility & $77 \cdot 7$ & $74 \cdot 5$ & 74.9 & $69 \cdot 5$ & - \\
\hline Biological value & $43 \cdot 8$ & $48 \cdot 9$ & $54 \cdot 1$ & $57 \cdot 1$ & 一 \\
\hline $\begin{array}{l}\text { Net protein utiliza- } \\
\text { tion }\end{array}$ & $34^{\circ} \cdot 0$ & $36 \cdot 4$ & $40 \cdot 7$ & $39 \cdot 7$ & - \\
\hline Utilizable nitrogen & $I \cdot 80$ & $2 \cdot 04$ & $2 \cdot 43$ & I 99 & - \\
\hline
\end{tabular}

The TD of the protein was between 70 and 80 , which agrees with the results of Luyken et al. (1961). The resultant NPU was between 30 and $40 \%$, which is relatively low. Owing to the high $\mathrm{N}$ content of the leaves, un ranged from $1 \cdot 80$ to $2 \cdot 43$ (Table 3 ), which is twice as much as for any cereal crop (Eggum, 1968b).

\section{Should the cassava leaf protein be supplemented with methionine?}

It is generally agreed that the methionine content of cassava leaf protein is low. Luyken et al. (196I) found a large increase in $\mathrm{BV}$ when cassava leaves were supplemented with synthetic methionine. To test this relationship, DL-methionine was added to cassava leaves, variety $6 \mathrm{I}_{5} 84$ Ohupon, giving a total amount of methionine as stated in Table 4.

Since Norwegian dried fish (cod) is used as a protein source in Nigeria, and West Africa generally, it was decided to test this combined with cassava leaves, and a diet 
was given in which $50 \%$ of the $\mathrm{N}$ was contributed by the dried fish and $50 \%$ by cassava leaves. The amino acid composition of the individual components, and the protein quality of both these and the mixed diets, are given in Table 4.

Table 4. Amino acid composition ( $g / \mathrm{I} 6 \mathrm{~g}$ nitrogen) and protein values of dried cod and of cassava leaves supplemented with methionine or dried cod

\begin{tabular}{|c|c|c|c|c|}
\hline Amino acid & $\begin{array}{c}\text { Cassava } \\
\text { (variety 61584 } \\
\text { Ohupon) }\end{array}$ & Dried cod & $\begin{array}{c}\text { Cassava } \\
\text { (variety } 61584 \\
\text { Ohupon) } \\
\text { +dried cod }\end{array}$ & $\begin{array}{c}\text { Cassava } \\
\text { (variety 61584 } \\
\text { Ohupon) } \\
\text { + methionine }\end{array}$ \\
\hline Lysine & $5 \cdot 87$ & 7.91 & - & - \\
\hline Methionine & I. 86 & $2 \cdot 92$ & - & - \\
\hline Cystine & 1.40 & r.03 & - & - \\
\hline Methionine + cystine & $3 \cdot 26$ & $3 \cdot 95$ & - & - \\
\hline Aspartic acid & $9 \cdot 77$ & $9.5 \mathrm{I}$ & - & - \\
\hline Threonine & $4: 39$ & 4.02 & - & - \\
\hline Serine & 4.55 & $4 \cdot 23$ & - & - \\
\hline Glutamic acid & $12 \cdot 32$ & 14.23 & - & - \\
\hline Glycine & 4.86 & 6.59 & - & - \\
\hline Alanine & 5.73 & 6.08 & - & - \\
\hline Valine & 5.56 & 4.53 & - & - \\
\hline Isoleucine & 4.50 & $4 \cdot 10$ & - & - \\
\hline Leucine & $8 \cdot 19$ & 7.20 & - & - \\
\hline Tyrosine & 4.04 & 3.03 & - & - \\
\hline Phenylalanine & $5 \cdot 42$ & 3.67 & - & - \\
\hline Histidine & $2 \cdot 30$ & $2 \cdot 22$ & -_- & - \\
\hline Arginine & $5 \cdot 34$ & $5 \cdot 88$ & - & - \\
\hline Tryptophan & I.99 & $1 \cdot 24$ & - & - \\
\hline $\mathrm{N}$ as $\%$ of dry matter & $5 \cdot 6 \mathrm{I}$ & 14.62 & - & - \\
\hline \multicolumn{5}{|c|}{ Protein value expressed as (\%): } \\
\hline True digestibility & $74 \cdot 5$ & $98 \cdot 4$ & $80 \cdot 7$ & $72 \cdot 1$ \\
\hline Biological value & 48.9 & $78 \cdot I$ & $72 \cdot 8$ & $80 \cdot 4$ \\
\hline Net protein utilization & $36 \cdot 4$ & $76 \cdot 8$ & $58 \cdot 7$ & $56 \cdot 5$ \\
\hline Utilizable nitrogen & $2 \cdot 04$ & II. 2 & - & $3 \cdot 2$ \\
\hline
\end{tabular}

Table 4 shows that dried cod contains a large amount of all the essential amino acids, including methionine. Because of the favourable amino acid composition, this protein has a good BV of 78 . The result of combining dried cod and cassava leaf shows, as might be expected, a great improvement in $\mathrm{BV}$ as compared with cassava leaf protein alone, the BV increasing from 49 to 73 . This clearly shows that combining cassava leaves and fish results in a greater utilization of the protein in the leaf.

The addition of methionine to cassava leaf also had a very positive effect on $\mathrm{BV}$, as this increased from 49 to 80 , an even higher value than for the combination with dried cod. un increased to $3.2 \%$, which is extremely high for a leaf product.

The results in Table 4 show quite definitely that the protein in cassava leaves contains too little of the sulphur-containing amino acids to obtain the best utilization of the protein. The practical question is whether enough is known for it to be safe to add synthetic methionine to a diet of cassava leaves. An overdose of a single amino acid may have an adverse effect (Eggum, 1967). However, a combination with a protein which has a high methionine content, such as dried cod, can surely be recommended. Alternatively, other good sources of methionine such as sunflower or sesame meal could possibly be used. 
True availability of the amino acids in cassava leaves and dried cod

The increased BV resulting from the addition of methionine indicates that there is a low availability of methionine in cassava leaves. The total content of sulphurcontaining amino acids in cassava leaves should theoretically result in a higher biological value than was found. To illustrate this relationship, the true availability of the amino acids in leaves boiled for ${ }_{5} 5$ min was measured and compared with the availability in dried cod: the results are given in Table 5 .

\section{Table 5. Availability (\%) of the individual amino acids in dried cod and boiled cassava leaves}

$\begin{array}{lcc}\text { Amino acid } & \text { Dried cod } & \begin{array}{c}\text { Boiled cassava leaves } \\ \text { (variety } 6 \mathbf{1} 584 \text { Ohupon) }\end{array} \\ \text { Lysine } & 99 \cdot 6 & 72 \cdot 8 \\ \text { Methionine } & 98 \cdot 7 & 59 \cdot 2 \\ \text { Cystine } & 99 \cdot 2 & 75 \cdot 3 \\ \text { Aspartic acid } & 97 \cdot 8 & 72 \cdot 3 \\ \text { Threonine } & 98 \cdot 8 & 62 \cdot 2 \\ \text { Serine } & 100 \cdot 0 & 84 \cdot 0 \\ \text { Glutamic acid } & 98 \cdot 9 & 64 \cdot 4 \\ \text { Glycine } & 98 \cdot 5 & 58 \cdot 7 \\ \text { Alanine } & 99 \cdot 5 & 64 \cdot 3 \\ \text { Valine } & 98 \cdot 7 & 55 \cdot 2 \\ \text { Isoleucine } & 98 \cdot 9 & 55 \cdot 2 \\ \text { Leucine } & 98 \cdot 8 & 61 \cdot 0 \\ \text { Tyrosine } & 96 \cdot 9 & 61 \cdot 5 \\ \text { Phenylalanine } & 96 \cdot 9 & 62 \cdot 5 \\ \text { Histidine } & 100 \cdot 0 & 71 \cdot 7 \\ \text { Arginine } & 99 \cdot 0 & 65 \cdot 8 \\ \text { Tryptophan } & 96 \cdot 9 & 78 \cdot 1 \\ \text { Total N } & 98 \cdot 4 & 66 \cdot 1\end{array}$

All the amino acids, and therefore the total $\mathrm{N}$, in dried cod were almost $100 \%$ available. Boiled cassava leaves behaved differently, and the availability of each individual amino acid varied considerably. Only $60 \%$ of the methionine was biologically available, and this probably accounted for the response obtained when methionine was added to the diet (Table 4 ).

The digestibility of total $\mathrm{N}$ in the boiled cassava leaves appeared to be lower than in the unboiled samples (Tables 3,4 ). This indicates that the digestibility of cassava leaf protein might be decreased by heating.

Special thanks are expressed to Dr Edvard Nordrum, The Agricultural College of Norway, who brought the samples from the Eastern Region, Nigeria (Biafra) and placed them at our disposal.

\section{REFERENCES}

Akinrele, I. A. (1963). $\mathfrak{l} l W$. Afr. Sci. Ass. 8, 74.

Byers, M. (1961). F. Sci. Fd Agric. 12, 20.

Dalziel, J. M. (1955). Useful Plants of West Tropical Africa and ed. London: Crown Agents.

Eggum, B. O. (1966). Z. Tierphysiol. Tierernähr. Futtermittelk. 22, 32.

Eggum, B. O. (1 967). Ugeskr. Agrom. no. 30 . 
Eggum, B. O. (1968a). Acta Agric. scand. I8, I27.

Eggum, B. O. (1968b). Aminosyrekoncentration og Proteinkvalitet pp. 76, 9, 33, 65. København: Stougaards Forlag.

Eggum, B. O. \& Mercer, N. H. (1964). Ugeskr. Landm. no. 5o.

Gerloff, E. D., Lima, I. H. \& Stahmann, M. A. (1965). F. agric. Fd Chem. 13, 139.

Irvine, F. R. (1952). Econ. Bot. 6, 23.

Luyken, R., de Groot, A. P. \& van Stratum, P. G. C. (I961). Nutritional Value of Foods from New Guinea. 2. Net Protein Utilization. Utrecht: Central Institute for Nutrition and Food Research TNO.

Moore, S., Spackman, D. H. \& Stein, W. H. (1958). Analyt. Chem. 30, 1185.

Oke, O. L. (1966). $\mathscr{f l} W$. Afr. Sci. Ass. I1, 42.

Oke, O. L. ( 1 968). Wld Rev. Nutr. Diet. 9, 227.

Okiy, G. E. O. (1960). $9 l W$. Afr. Sci. Ass. 6, I I7.

Rogers, D. J. (1959). Econ. Bot. 13, 261.

Rogers, D. J. \& Milner, M. (1963). Econ. Bot. x7, 2 I I.

Singh, N. (1964). F. Fd Sci. Technol. r, 37.

Terra, G. J. A. (1964). Trop. geogr. Med. 2, 97.

Van Veen, A. G. (1938). Geneesk. Tijdschr. Ned.-Indië 78, 2548.

Weidner, K. \& Eggum, B. O. (1966). Acta Agric. scand. 16, I 5. 